Research Article

\title{
Experimental evaluation of the anti-ulcer activity of the ethanolic extract of grape (Vitis vinifera) seed in wistar albino rats against aspirin plus pylorus ligation induced gastric ulcer model
}

\author{
Anand M. Ingale ${ }^{1 *}$, Venkata Bharat Kumar Pinnelli ${ }^{2}$, Vijaya Rajendran ${ }^{1}$
}

\begin{abstract}
${ }^{1}$ Department of Pharmacology, ${ }^{2}$ Department of Biochemistry Vydehi Institute of Medical Sciences and Research Centre, Bangalore, India
\end{abstract}

Received: 11 February 2016 Accepted: 14 March 2016

*Correspondence to:

Dr. Anand M. Ingale,

Email: dr.anandingale

@ gmail.com

Copyright: (C) the author(s), publisher and licensee Medip Academy. This is an openaccess article distributed under the terms of the Creative Commons Attribution NonCommercial License, which permits unrestricted noncommercial use, distribution, and reproduction in any medium, provided the original work is properly cited.

\begin{abstract}
Background: There is an increased demand for newer safer drugs for the treatment of peptic ulcer disease as its incidence is increasing gradually in view of changing lifestyle and stress. The objective of this study was to evaluate the anti-ulcer activity of ethanol extract of seeds of Vitis vinifera.

Methods: The ethanol extract of Vitis vinifera was investigated for its anti-ulcer activity in rats against Aspirin plus Pylorus ligation induced gastric ulcer.

The antiulcer activity was assessed by determining and comparing gastric volume, $\mathrm{pH}$, free and total acidity; ulcer number and its inhibition, ulcer severity and ulcer index.

Results: A significant antiulcer activity was observed. Pylorus ligation model showed significant $(\mathrm{p}<0.01)$ reduction in gastric volume, free acidity and ulcer index as compared to control.

Conclusions: This present study indicates that Vitis vinifera seed extract have potential anti-ulcer activity in the model tested.
\end{abstract}

Keywords: Vitis vinifera, Anti-ulcer, Aspirin, Pylorus ligation, Free acidity, Total acidity

\section{INTRODUCTION}

Peptic ulcer disease is a common disease of the gastrointestinal tract, occurring as a result of an imbalance between the aggressive and the defensive factors controlling the normal physiology of the stomach. ${ }^{1}$ The patients usually have the features of heart burn and stomach pain. It is accurately diagnosed through endoscopy. $^{2}$

Though, various drugs with specific mechanism have been developed for its management, they are not totally safe and effective. ${ }^{3}$ Extensive research is been undertaken to explore newer options for its treatment. Herbal products, with better safety and efficacy profile, find an important place in the management of the condition. ${ }^{4}$

Grape plant is a commonly growing creeper in world, including India. The various parts of the plant like fruit, leaves and root have high nutritional and medicinal values. ${ }^{5}$ They form an important part in the therapy of many clinical conditions.

Grape seed is a part of the fruit. It is a waste product in wine industry. Grape seed extract (GSE) has high contents of phytonutrients like flavonoids, which is linked to most of its activities. 
GSE has been proven of numerous activities like antioxidants and they also possess antibacterial effects against $\mathrm{H}$. pylori and MRSA, anti-inflammatory action cardiovascular and endothelial protection, antihepatotoxic action, adaptogenic and nootropic effects, platelet function, apoptosis, aromatase inhibitor, vascular endothelial growth factor (VEGF) and angiogenesis inhibition, antiviral and antifungal properties. ${ }^{6-16}$ Most of the activities of GSE are attributed to their antioxidant activity. GSE is shown to have antiulcer activity, effect on ethanol and stress induced gastric lesions. ${ }^{17,18}$

The present study was thus undertaken to explore its possible antiulcer activity through aspirin-pylorus ligation method.

\section{METHODS}

The present study is undertaken only after being approved by our institutional animal ethical committee. The guidelines of committee for the purpose of control and supervision of experimental animals (CPCSEA) have been strictly followed throughout the study.

\section{Plant}

\section{Preparation of the grape seed extract}

Grape seeds were removed from the grapes and air dried for 1 week. $100 \mathrm{~g}$ of dried seeds were taken and soaked in $300 \mathrm{ml}$ of ethanol (95\%), with occasional stirring for 24 hours. Filter out infusion by a piece of filter cloth. Supernatant was collected and kept aside. To the left out residue of grape seeds once again it was soaked in $300 \mathrm{ml}$ ethanol (95\%), above procedure repeated twice. The entire supernatant layer collected and concentrated at $500 \mathrm{c}$ with vacuum in rotary evaporator.

\section{Animal}

Inbred wistar albino rats (Ratus norvegicus) of either sex, weighing 150 to 250 grams, acclimatized to the laboratory conditions for two weeks, were used for the study. They were housed in clean polypropylene cages, in a well-ventilated room at controlled temperature (26$280^{\circ} \mathrm{C}$ ) with a 12 hour light and dark cycle. All experiments were performed during the same time of the day to avoid diurnal variations of gastric functions.

\section{Drugs and chemicals}

All the chemicals used in this evaluation were of high grade and purity;

- Ranitidine powder (Saraca Laboratories Limited)

- Aspirin powder (Medopharm)

- Topfers reagent (Merck and Co.)

- Phenolphthalein indicator, Sodium hydroxide $(0.01 N)$ (S. D. Fine Chem. Ltd)

\section{Procedure}

Healthy wistar albino rats were divided into four groups of six rats each as follows;

Group 1 (Control): received $1 \mathrm{ml}$ distilled water orally Group 2 (Standard): treated with standard $(50 \mathrm{mg} / \mathrm{kg}$ ranitidine) orally

Group 3 (GSE 100): treated with $100 \mathrm{mg} / \mathrm{kg}$ of grape seed extract orally

Group 4 (GSE 200): treated with $200 \mathrm{mg} / \mathrm{kg}$ of grape seed extract orally.

The procedure was followed according to Malairajan et al. ${ }^{19} 200 \mathrm{mg} / \mathrm{kg}$ aspirin (suspended in $1 \%$ carboxy methyl cellulose) and either distilled water $(1 \mathrm{ml})$ or grape seed extracts $(100,200 \mathrm{mg} / \mathrm{kg})$ are administered orally through an intragastric polythene tubing (gavage) once daily for 3 days. The rats were fasted (food-withdrawn, water given ad libitium) 36 hours before the pylorus ligation, during which they were housed singly to prevent cannabalism and coprophagy. On the fourth day, the pylorus was ligated under light ether anaesthesia. The abdomen was cut opened by a small incision below the xiphoid process, through which the pyloric portion of stomach was slightly lifted out and ligated avoiding traction to the pylorus or damage to its blood supply. The pylorus was replaced back carefully and the abdominal wall is closed by interrupted sutures. The animals were deprived of food and water during the postoperative period and were sacrificed after 4 hours of pylorus ligation by cervical dislocation. The stomach was excised after tying both the ends of stomach. The gastric contents were drained into centrifuge tube and observed for its $\mathrm{pH}$ and volume. The free and total acidity were estimated. The stomach was opened along its greater curvature and fixed on the frog board. It was then observed for the number of ulcers, their severity, gastric lesion and ulcer index. ${ }^{19}$

\section{Parameters}

\section{Estimation of $\mathrm{pH}$ and gastric volume}
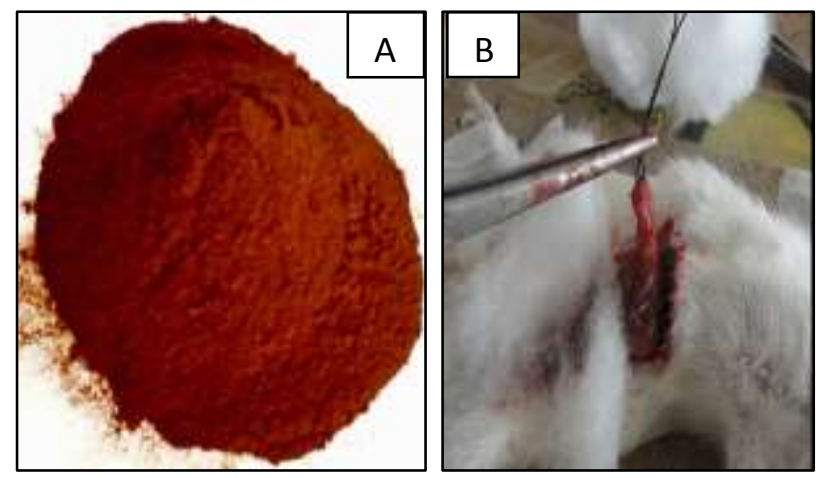

Figure 1: (A) Grape seed extract; (B) pylorus ligation.

The contents of the stomach obtained, was centrifuged at the speed of 1000 revolutions per minute for 20 minutes. 
The supernatant fluid obtained, was collected and its volume was estimated. The $\mathrm{pH}$ of the content was noted by means of $\mathrm{pH}$ strips by matching the colour obtained with that of the reference standard.

\section{Estimation of free and total acidity}

The gastric content obtained was diluted to $10 \mathrm{ml}$ by adding distilled water and in a conical flask. ${ }^{20}$ This fluid was analysed for its free and total acidity by titrating it against $0.01 \mathrm{~N} \mathrm{NaOH}$ solution. The initial recording of the fluid level (A) in the burette was noted. 1 to 2 drops of Topfers reagent (di-methyl amino azobenzene in $95 \%$ alcohol) were added to the conical flask contents and titration was done by constant mixing with the contents of the conical flask. The level at which the colour change from red to yellowish orange occurred, that corresponded to the free acidity, was noted (B). The volume of $\mathrm{NaOH}$ consumed (B-A) was recorded. Free acidity was calculated by the formula: Free acidity = Volume of $\mathrm{NaOH}$ (B-A)*Normality*100/0.1. The titration was continued by adding phenolphthalein indicator to the conical flask contents and the level at which the colour change from yellowish orange to slight pink occurred was noted. This corresponded to the total acidity and the value was recorded as (C). The volume consumed (C-A) was noted. Total acidity was calculated by the formula: Total acidity $=$ Volume of $\mathrm{NaOH}(\mathrm{C}-\mathrm{A}) *$ Normality*100/0.1. Free acidity and Total acidity were expressed in $\mathrm{mEq} / \mathrm{litre} / 100 \mathrm{gm}^{20}$

\section{Estimation of ulcer number}

The gastric mucosa was observed macroscopically under 10x magnifications. The number of superficial ulcers, deep ulcers and perforations were noted. The total number of ulcers in each rat was recorded. ${ }^{21}$

\section{Estimation of gastric lesion}

Gastric lesion of all possible ulcers was recorded by measuring its longest diameter (in $\mathrm{mm}$ ) by means of divider and graph paper. Total gastric lesion in each rat was calculated. $^{22}$

\section{Estimation of ulcer severity}

The ulcers in each rat were graded as: ${ }^{23}$

0 - No ulcers

1 - Superficial ulcers

2 - Deep ulcers

3 - Perforations

Average severity score of each group was calculated. ${ }^{23}$

\section{Estimation of ulcer index}

Ulcer index in each group was calculated by the formula $^{23}: \mathrm{UI}=\mathrm{UN}+\mathrm{US}+\mathrm{UP} * 10-1$
Where, UI = Ulcer Index; UN = Average of number of ulcer per animal;

US = Average of severity score and UP $=$ Percentage of animal with ulcer.

\section{Statistical analysis}

The data were expressed as mean \pm SEM. Results were analysed statistically by One-way ANOVA (analysis of variance) followed by Dunnett's t test using standard statistical software package of social science (SPSS) version 20. All the groups were compared with the control group in each model. The difference was considered significant if $\mathrm{p}<0.05$.

\section{RESULTS}

In the aspirin-pylorus ligation model analysed, grape seed $100 \mathrm{mg} / \mathrm{kg} / \mathrm{p} .0$. group caused significant $(\mathrm{p}<0.05)$ reduction in the Gastric volume $1.10 \pm 0.02$ (Figure 3), Total acidity $36.16 \pm 0.60$, Bound acidity 5.5 \pm 1.02 (Figure 4), ulcer number $33.33 \pm 1.52$ and gastric lesion $19.33 \pm 1.68$ (Table 1) when compared with the control group. There was no significant change in the $\mathrm{pH}$ $1.00 \pm 0.0$ (Figure 5), free acidity 30.66 \pm 1.35 (Figure 4), and severity $2.00 \pm 0.0$ (Table 1) when compared with the control group.
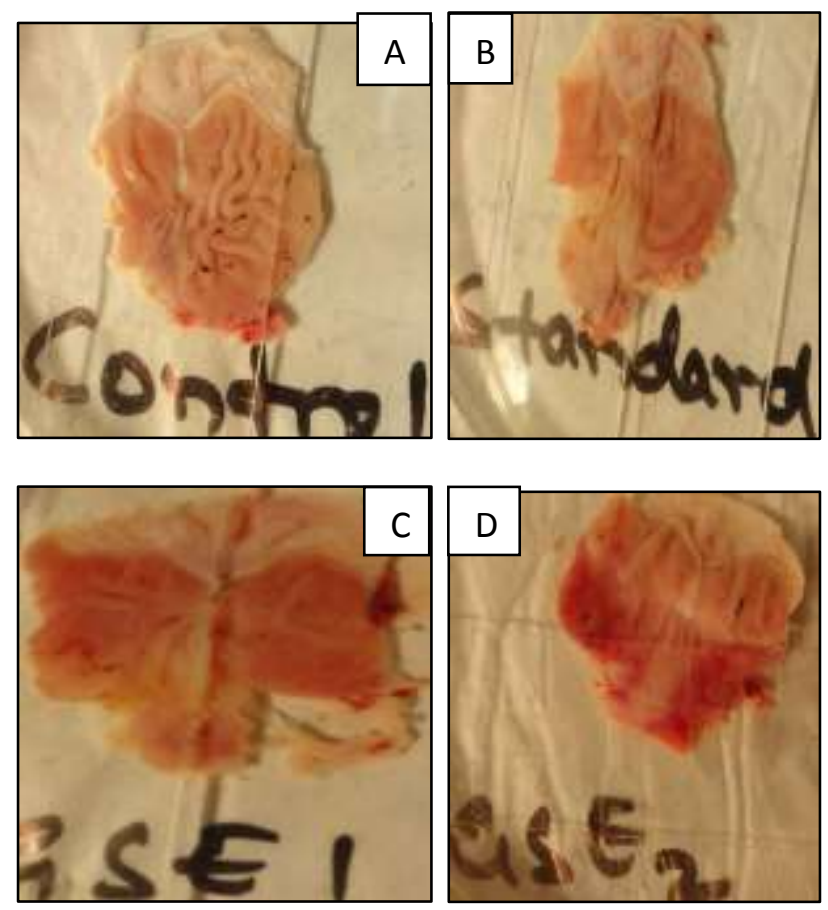

Figure 2: Stomach mucosa of rat in aspirin-pylorus ligation model; (A) control group; (B) standard group; (C) grape seed extract $100 \mathrm{mg} / \mathrm{kg}$; (D) grape seed extract $200 \mathrm{mg} / \mathrm{kg}$. 


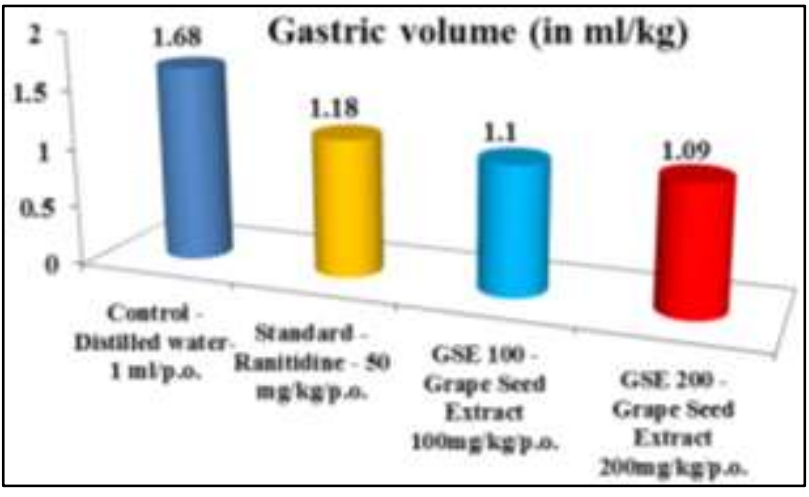

Figure 3: The effect of GSE (100 mg, $200 \mathrm{mg} / \mathrm{kg})$ in aspirin-pylorus ligation model on gastric volume.

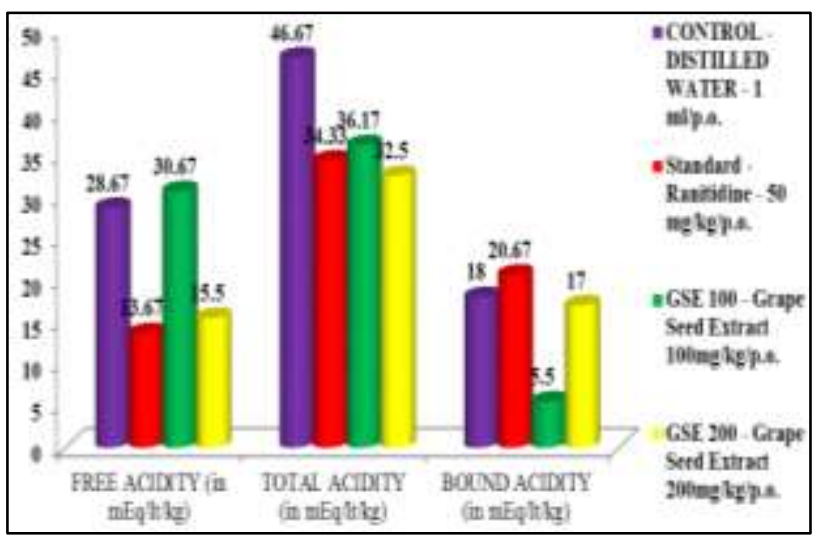

Figure 4: The effect of GSE $(100 \mathrm{mg}, 200 \mathrm{mg})$ in aspirin-pylorus ligation model on free, total and bound acidity.

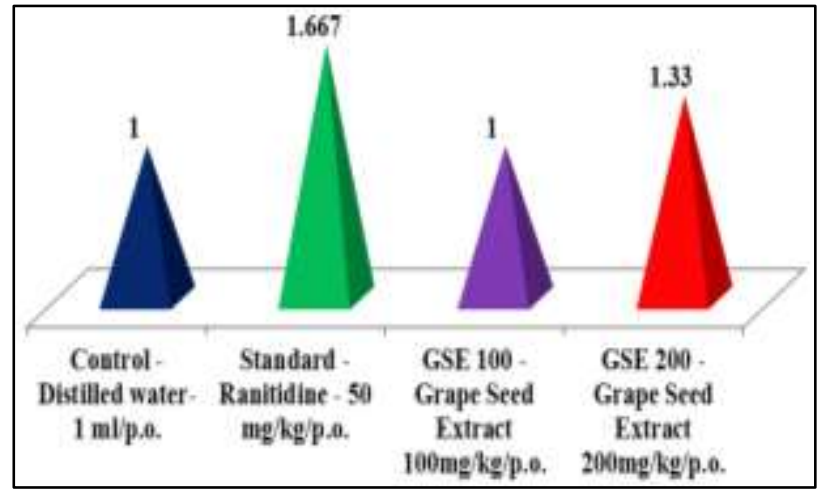

Figure 5: The effect of GSE $(100,200 \mathrm{mg})$ in aspirinpylorus ligation model on $\mathbf{p H}$.

Percentage ulcer inhibition (decrease in the number of ulcers) with grape seed $100 \mathrm{mg} / \mathrm{kg}$ group was $58.93 \%$ and with grape seed $200 \mathrm{mg} / \mathrm{kg}$ group was $68.99 \%$ when compared with the control group (Table 1).

The ulcer index determined was 93.49 for the control group, 43.83 for the standard group, 45.33 for grape seed $100 \mathrm{mg} / \mathrm{kg}$ group and 36.66 for grape seed $200 \mathrm{mg} / \mathrm{kg}$ group. And the ulcer protection was $53.11 \%, 51.51 \%$ and $60.78 \%$ for the standard, $100 \mathrm{mg} / \mathrm{kg}$ and $200 \mathrm{mg} / \mathrm{kg}$ group respectively (Table 1$)$.

The grape seed $200 \mathrm{mg} / \mathrm{kg} / \mathrm{p}$.o. group caused significant $(\mathrm{p}<0.05)$ reduction in the gastric volume $1.09 \pm 0.06$ (Figure 3), free acidity $15.5 \pm 1.17$ and total acidity $32.5 \pm 1.45$ (Figure 4), ulcer number 25.66 \pm 2.21 , severity $1.00 \pm 0.0$ and gastric lesion $12.83 \pm 1.60$ (Table 1) as compared to the control group. There was no

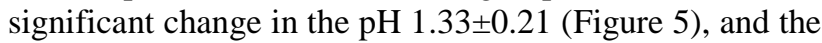
bound acidity $17.0 \pm 1.57$ (Figure 4 ).

Table 1: Effect of grape seed extract in aspirin plus pylorus ligation on various ulcer parameters.

\begin{tabular}{|lllllllll|}
\hline Treatment & \multicolumn{2}{c}{ Dose $(\mathrm{mg} / \mathrm{kg})$} & \multicolumn{2}{c}{ Ulcers number } & Total & $\begin{array}{l}\text { Inhibition } \\
(\%)\end{array}$ & $\begin{array}{l}\text { Gastric lesion } \\
(\mathbf{i n ~ m m})\end{array}$ & \multicolumn{2}{c}{ Ulcer index } & Total & $\begin{array}{l}\text { Protection } \\
(\%)\end{array}$ & $\begin{array}{l}\text { Average severity } \\
\text { score }\end{array}$ \\
\hline $\begin{array}{l}\text { Control group } \\
\text { (distilled water) }\end{array}$ & $1 \mathrm{ml}$ & $81.16 \pm 1.07$ & 0.0 & $34.00 \pm 4.64$ & 93.49 & 0.0 & 2.33 \\
\hline $\begin{array}{l}\text { Standard } \\
\text { (ranitidine) }\end{array}$ & 50 & $32.83 \pm 1.07^{*}$ & 59.54 & $15.5 \pm 2.12^{*}$ & 43.83 & 53.11 & 1 & \\
\hline Grape seed extract & 100 & $33.33 \pm 1.52^{*}$ & 58.93 & $19.33 \pm 1.68^{*}$ & 45.33 & 51.51 & 2 \\
\hline Grape seed extract & 200 & $25.66 \pm 2.21^{*}$ & 68.99 & $12.83 \pm 1.60^{*}$ & 36.66 & 60.78 & 1 \\
\hline
\end{tabular}

Values are expressed as Mean \pm SEM. $n=6$. ${ }^{*} \mathrm{p}<0.05$ as compared to control

\section{DISCUSSION}

In the present study, the evaluation of the anti-ulcer activity of the ethanolic extract of grape seed extract was done using their two doses $(100,200 \mathrm{mg} / \mathrm{kg})$ in wistar albino rats using the Aspirin-pylorus ligation model, which is a well proven and commonly employed model presently. ${ }^{24}$ This model evaluates the anti-secretory $(\mathrm{H} 2$ antagonism) property of the GSE.

In this model, Ligation of the pylorus causes stasis of the acidic gastric contents in the stomach, which further 
causes auto-digestion of the gastric mucosa precipitating an imbalance between the aggressive and defensive factors operating in the gastric lumen giving rise to ulcers in the rat stomach. There is also breakdown of the gastric mucosal barrier. ${ }^{21}$ Aspirin, which is a NSAID, causes irreversible inhibition of the cyclooxygenases enzyme that synthesizes prostaglandins, which have a protective role in the gastric mucosa. Inhibition of prostaglandins diminishes the defensive ability of the stomach giving rise to ulcer formation. Aspirin increases acid secretion and back diffusion of $\mathrm{H}^{+}$ions into the mucosa also. ${ }^{21}$ Both of them increase the stress in the gastric lumen. They increase the generation of free radicals that precipitates the oxidative stress in the gastric lumen leading to ulcer formation. Synergistic effect of pylorus ligation and aspirin precipitates ulcer formation and enhances the efficacy of screening anti-ulcer agents. ${ }^{23}$

In our study, $100 \mathrm{mg} / \mathrm{kg}$ and $200 \mathrm{mg} / \mathrm{kg}$ grape seed extract significantly decreased the gastric volume, free and total acidity, ulcer number, gastric lesion and ulcer severity. Ulcer index, which is attributed to different parameters like number of ulcers, ulcer severity was decreased by $51.51 \%$ with GSE 100 and $60.78 \%$ with GSE 200 .

The ethanolic extract of grape seed showed a significant decrease in the gastric volume with both $100 \mathrm{mg} / \mathrm{kg}$ and $200 \mathrm{mg} / \mathrm{kg}$ groups when compared with the control group. This enumerates its activity as an anti-secretory agent. This can be correlated to the proanthocyanidine content of GSE, that are powerful antioxidants. ${ }^{25}$ Being antioxidants, they may inhibit the generation of oxidative stress and stop the oxidative process leading to ulcer formation. ${ }^{26}$ The higher dose of the grape seed extract produces more reduction. This can be attributable to the higher proanthocyanidine content of the extract. ${ }^{27}$

The extract increased the $\mathrm{pH}$ in both the groups with 100 $\mathrm{mg} / \mathrm{kg}$ and $200 \mathrm{mg} / \mathrm{kg}$ groups as compared to the control group but the rise was not significant. As the $\mathrm{pH}$ was noted by means of $\mathrm{pH}$ strips colorimetrically, by comparing with the reference standard, the accurate recording of the $\mathrm{pH}$ could not be done.

Significant decrease in the free acidity was seen in the grape seed $200 \mathrm{mg} / \mathrm{kg}$ group and that of total acidity was seen in both the grape seed $100 \mathrm{mg} / \mathrm{kg}$ and grape seed 200 $\mathrm{mg} / \mathrm{kg}$ group as compared to their control groups. The results show that grape seed extract possessing proanthocyanidins cause decrease in the free and total acidity and the activity with both grape seed $100 \mathrm{mg} / \mathrm{kg}$ and $200 \mathrm{mg} / \mathrm{kg}$ and grape seed $100 \mathrm{mg} / \mathrm{kg}$ decreases only the total acidity. It shows that higher concentration of the extract possesses better activity on account of their higher proanthocyanidines that are antioxidants as well as gastroprotective agents. $^{22,27,28}$

Significant decrease in the number of ulcers was seen in grape seed $100 \mathrm{mg} / \mathrm{kg}$ group and $200 \mathrm{mg} / \mathrm{kg}$ group. As there was a reduction in the volume of gastric contents and also a rise in $\mathrm{pH}$ of gastric contents, there was a decrease in the number of ulcers in the study groups. This change can also be related to the proanthocyanidins that possess powerful antioxidant activity that inhibits or reverses the oxidative process and thus benefiting in the process. $^{8}$ Percentage decrease in the number of ulcers with grape seed $100 \mathrm{mg} / \mathrm{kg}$ group was $58.93 \%$ and with grape seed $200 \mathrm{mg} / \mathrm{kg}$ group was $68.99 \%$ when compared with the control group proving that higher concentration of the extract possessed improved and better activity.

Significant decrease in gastric lesion was seen in both grape seed $100 \mathrm{mg} / \mathrm{kg}$ and $200 \mathrm{mg} / \mathrm{kg}$. Gastric lesions represented the area of the ulcers formed in the gastric mucosa. As there was significant decrease in the number of ulcers, the area of them also was found to be decreased.

Significant decrease in the severity of the ulcers in the grape seed $200 \mathrm{mg} / \mathrm{kg}$ group was seen. Grape seed with higher concentration $(200 \mathrm{mg} / \mathrm{kg})$ caused significant reduction in the severity that can be accounted to their high polyphenol concentration that is rich antioxidant. ${ }^{25}$

Ulcer index was used for the analysis as ulcer formation is directly related to factors such as gastric volume, free and total acidity. ${ }^{21}$ In case of vehicle control, aspirin plus pylorus ligation caused increased the acid secretion, which in turn caused increase in gastric volume, low $\mathrm{pH}$, increased the free and total acidity resulting into increased ulcer index. The percentage decrease in the ulcer index was $51.51 \%$ for grape seed $100 \mathrm{mg} / \mathrm{kg}$ group and $60.78 \%$ for grape seed $200 \mathrm{mg} / \mathrm{kg}$ group.

\section{ACKNOWLEDGEMENTS}

The authors gratefully acknowledge the Director of Vydehi Institute of Medical Sciences and Research Centre, Whitefield, Bangalore, for kind support throughout our study. We extend our thanks to Olive Life Sciences, Bangalore for providing the Grape Seed Extract.

\section{Funding: No funding sources \\ Conflict of interest: None declared \\ Ethical approval: The study was approved by the Institutional Ethics Committee}

\section{REFERENCES}

1. Kumar, Abbas, Fausto, Aster, Robbins, Cotran. Pathological basis of diseases. $8^{\text {th }}$ ed. Pennsylvannia: Elsevier Saunders publishers; 2010.

2. McPee SI, Papadakis MA. Current medical diagnosis and treatment. NewDelhi: Mc Graw Hill Lange Publications; 2012.

3. Brunton LL. Goodman and Gilman's the pharmacological basis of therapeutics. $12^{\text {th }}$ edition. China: McGraw Hill Medical Company; 2012.

4. Department of pharmacology and therapeutics. herbal medicines: an evidence based look. The University of British Columbia. Canada: The University of British Columbia; 1998.

5. Grapes. Available at http://www.whfoods.com. Accessed 09 October 2013. 
6. Vaughan JG, Geissler CA. The New Oxford Book of Food Plants (revised and updated edition): New York: Oxford University Press; 1997.

7. Brown JC, Huang G, Haley-Zitlin V, Jiang $\mathrm{X}$. Antibacterial effects of grape extracts on Helicobacter pylori. Appl Environ Microbiol. 2009;75(3):848-52.

8. Al-Habib A, Al-Saleh E, Safer A, Afzal M. Bactericidal effect of grape seed extract on Methicillin-resistant Staphylococcus aureus (MRSA). J Toxicol Sci. 2010;35(3):357-64.

9. Wen-Guang L, Xiao-Yu Z, Xuan T. Antiinflammatory effect and mechanism of proanthocyanidines from grape seeds. Acta Pharma9col Sin. 2001;22(12):1117-20.

10. Clifton PM. Effect of grape seed extract and quercition on cardiovascular and endothelial parameters in high-risk subjects. J Biomed Biotechnol. 2004:5:272-8.

11. Maheswari UM, Rao PGM. Antihepatotoxic effect of grape seed oil in rat. Indian Journal of Pharmacology. 2004;37(3):179-82.

12. Sreemantula S, Nammi S, Kolanukonda R, Koppula S, Boini KM. Adaptogenic and nootropic activities of aqueous extract of Vitis vinifera (grape seed): an experimental study in rat model. Biomed Central Complement of Alternate Medicine. 2005;5:1.

13. Vitseva O, Varghese S, Chakrabarti S, Folts JD, Freedman JE. Grape seed and skin extracts inhibit platelet functionand release of reactive oxygen intermediates. J Cardiovasc Pharmacol. 2005;46:445-51.

14. Roy AM, Baliga MS, Elmets CA, Katiyar SK. Grape seed proanthocyanidins induce apoptosis through, bax, and caspase 3 pathways. Neoplasia. 2005;7(1):24-36.

15. Kijima I, Phung S, Hur G, Kwok S, Chen S. Grape seed extract is an aromatase inhibitor and a suppressor of aromatase expression. Cancer Res. 2006;66(11):5960-7.

16. Wen W, Lu J, Zhang K, Chen S. Grape seed extract (GSE) inhibits angiogenesis via suppressing VEGFR signaling pathway. Cancer Prev Res (phila). 2008; 17:544-61.

17. Kim TO, Jeon EJ, Cheung DY, Kim CW, Kim SS, Park S, et al. Gastroprotective effects of grape seed proanthocyanidin extracts against nonsteroid anti- inflammatory drug-induced gastric injury in rats. Gut and Liver. 2013;7(3):282-9.

18. Cuevas VM, Calzado YR, Guerra YP, Year AO, Despaigne SJ, Ferreiro RM, et al. Effects of grape seed extract, vitamin $\mathrm{C}$, and vitamin $\mathrm{E}$ on ethanoland aspirin-induced ulcers. Advances in Pharmacological Sciences. 2011:1-6.

19. Malairajan P, Gopalakrishnan G, Narasimhan S, Veni KJK. Evaluation of anti-ulcer activity of Polyalthia Longifolia (Sonn.) Thwaites in experimental animals. Indian J Pharmacol. 2008;40(3):126-8.

20. Firdous SM, Neraja K , Debnath R, Singha D, Sravanthi K. Evaluation of antiulcer activity of ethanolic extract of sechium edule fruits in experimental rats. Int J Pharm Sci. 2012;4(1):374-7.

21. Bickel M. Activity on gastrointestinal tract. in In: Vogel GH, Vogel WH, Scholkens BA, Sandow J, Muller G. , Vogel W F. Drug discovery and evaluation. Pharmacological assays. $2^{\text {nd }}$ ed. Germany: Springer Publications; 2002:867-872.

22. Ingale AM, Rajendran V, Pinnelli VB. Experimental evaluation of the anti-ulcer activity of grape (vitis vinifera) seed extract in wistar albino rats. International Journal of Applied Biology and Pharmaceutical Technology. 2014;5(4):107-12.

23. Mittal R, Bhardwaj RK. Antiulcer agents. In: Gupta SK. Drug Screening Methods. $2^{\text {nd }}$ ed. New Delhi: Jaypee Brothers Medical Publishers (P) ltd.; 2009.

24. Fine AM. Oligomeric proanthocyanidin complexes: history, structure, and phytopharmaceutical applications. Altern Med Rev. 2000;5(2):144-51.

25. Shi J, Yu J, Pohorly JE, Kakuda Y. Polyphenolics in grape seeds- biochemistry and functionality. Journal of Medicinal Food. 2003;6(4):291-9.

26. Ingale AM, Rajendran V, Pinnelli VB. A comparative evaluation of the anti-ulcer activity of the extracts of seed and skin of vitis vinifera (grape) in wistar albino Rats. Intl J Clin Diag Res. 2014;2(2):I.

27. Saito M, Hosoyama H, Ariga T, Kataoka S, Yamaji N. Antiulcer activity of grape seed extract and procyanidins. Journal of Agricultural and Food Chemistry. 1998;46(4):1460-4.

28. Sandhar HK, Kumar B, Prasher S, Tiwari P, Salhan M, Sharma PA. Review of phytochemistry and pharmacology of flavonoids. Internationale Pharmaceutica Sciencia. 2011;1(1):25-41.

Cite this article as: Ingale AM, Pinnelli VB, Rajendran $\mathrm{V}$. Experimental evaluation of the anti-ulcer activity of the ethanolic extract of grape (Vitis vinifera) seed in wistar albino rats against aspirin plus pylorus ligation induced gastric ulcer model. Int J Basic Clin Pharmacol 2016;5:722-7. 